UDC 930.2:329.73(477)“"1935"

DOI: $10.24919 / 2519-058 x .14 .197184$

\title{
Ivan GRYCENKO
}

PhD hab. (Law), Professor, Dean of the Law Faculty of Taras Shevchenko National University of Kyiv,60 Volodymyrska Street, Kyiv,Ukraine, postal code 01601 (i.s.grycenko@ukr.net)

ORCID: https://orcid.org/0000-0002-4236-3999

\section{Andrii SHCHEHLOV}

PhD (History), Army Scientific Center Leading Researcher, Hetman Petro Sahaidachnyi National Army Academy, 32 Heroiv Maidanu Street, Lviv, Ukraine, postal code 79012 (deep_in_faith@ukr.net)

ORCID: https://orcid.org/0000-0002-6484-0864

\section{Іван ГРИЦЕНКО}

доктор юридичних наук, професор, декан юридичного факультету Київського національного університету імені Тараса Шевченка, вул. Володимирська, 60, Київ, Україна, індекс01601 (i.s.grycenko@ukr.net)

\section{Андрій ЩЕГЛОВ}

кандидат історичних наук, провіднийнауковий співробітник Наукового иентру Сухопутних військ Національної академії Сухопутних військ імені гетьмана Петра Сагайдачного, вулиия Героїв Майдану, 32, Львів, Украӥна, індекс 79012 (dеep_in_faith@ukr.net)

Бібліографічний опис статті: Grycenko, I. \& Shchehlov, A. (2020). Statute of the Ukrainian National Cossack Movement (UNAKOR) (1935) as a historical source. Skhidnoievropeiskyi Istorychnyi Visnyk [East European Historical Bulletin], 14, 117-129. doi: 10.24919/2519-058x.14.197184

\section{STATUTE OF THE UKRAINIAN NATIONAL COSSACK MOVEMENT (UNAKOR) (1935) AS A HISTORICAL SOURCE}

\begin{abstract}
The purpose of the research is to publish and analyze the statute of the Ukrainian National Cossack Movement (UNAKOR) (1935) as a source for the history of the specified organization and legal culture of the Ukrainian Cossack movement. The research methodology - principles of scientificity, objectivity, historicism, methods of external and internal critique of sources. The research novelty is that the Statute of the Ukrainian National Cossack Movement (UNAKOR) (1935) was first published and analyzed as a historical and historical and legal source. The Conclusions. Thus, the Statute of the Ukrainian National Cossack Movement (UNAKOR) was approved on 1 June 1935 by the UNAKOR Military Authority and signed by military clerk I. Voloshyn and military osavul V. Zolotarenko. Although this document is known to researchers, it has not been analyzed separately as a historical source. The statute in its original version is kept in the Sectoral State Archive of the Security Service of Ukraine and the Central State Archives of Higher Authorities and Administration of Ukraine in Kyiv. In this article we use a document from the Sectoral State Archives of the Security Service of Ukraine. The Statute is divided into three sections: I - a historical sketch of the movement (10 subparagraphs); II - UNAKOR program (26 subparagraphs); III - UNAKOR Regulamine (19 subparagraphs).
\end{abstract}


We consider it an important historical source for the history of the functioning of the whole Cossack movement and the history of the development of domestic legal thought.

The document is published in the original language. The edition retains the vocabulary, authoring and editorial features of the source as much as possible. Own and geographical names are presented without changes. Only the most obvious grammatical errors were corrected. The document is accompanied by a legend, indicating the place of its storage (the name of the archive, the number of the fonds, descriptions, cases, pages).

Key words: UNAKOR, Volhyn, Ivan Poltavets-Ostrianytsia.

\title{
СТАТУТ УКРАЇНСЬКОГО НАЦІОНАЛЬНОГО КОЗАЦЬКОГО РУХУ (УНАКОР) (1935 Р.) ЯК ІСТОРИЧНЕ ДЖЕРЕЛО
}

\begin{abstract}
Анотація. Мета дослідження - опублікувати і проаналізувати статут Украӥнського наиіонального козацького руху (УНАКОР) (1935) як джерело до історії зазначеної організачії та правової культури українського козаџького руху. Методологія дослідження - принципи науковості, об'єктивності, історизму, методи зовнішньої та внутрішньої критики джерел. Наукова новизна полягає у тому, що уперше публікується Статут Украйнського національного козацького руху (УНАКОР) (1935) та здійснюється його аналіз як історичного та історико-правового джерела. Висновки. Отже, Статут Украӥнського наџіонального козаџького руху (УНАКОР) було затверджено 1 червня 1935 р. військовою Управою УНАКОР та підписано військовим писарем I. Волошином і військовим осавулом В. Золотаренком. Попри те, щзо ией документ відомий дослідникам, він окремо не аналізувався як історичне джерело. Статут в оригінальній редакиії зберігається у Галузевому державному архіві Служби безпеки України і Центральному державному архіві вищих органів влади та управління Украӥни в м. Київ. У ичй статті використовусмо документ із Галузевого державного архіву Служби безпеки Украӥни. Статут складається із трьох розділів: I- історичний нарис руху (10 підпунктів); II - програма УНАКОР (26 підпунктів); III - регулямін УНАКОР (19 підпунктів). Вважаємо його важливим історичним джерелом до історії функиіонування иілого козацького руху та історії розвитку вітчизняної правової думки.

Документ публікуеться мовою оригіналу. У виданні максимально збережено лексику, авторські та редакторські особливості джерела. Без змін подано власні та географічні назви. Виправленню підлягали лише найбільш очевидні граматичні огріхи. Документ супроводжується легендою, в якій зазначено місие його зберігання (назва архіву, номер фонду, опису, справи, аркушів).
\end{abstract}

Ключові слова: УНАКОР, Волинь, Іван Полтавець-Остряниця.

The Problem Statement. Participants of the national liberation competitions of 1917 1921 who went to emigration did not abandon the idea of continuing the struggle. In January 1923, I. Poltavets-Ostrianytsia founded the Ukrainian National Cossack Society (UNAKOTO) in Munich. This military organization aimed to unite and restore the independence of Ukraine to lead, which was to be headed by a hetman with unlimited power. UNAKOTO used elements of national-socialist ideology. In the programming documents, democratic principles of government were rejected, and discriminatory provisions were introduced against representatives of other nationalities. In 1923 - 1924, UNAKOTO had its own printed body the illustrated monthly "Ukrainian Cossack" (Sectoral State Archive of Security Service of Ukraine (SSA SSU), f. 2, description 8 (1959), case 3, p. 130). The need to intensify the Cossack movement, to attract new members, to modernize the program forced I. PoltavetsOstrianytsia to liquidate UNAKOTO and to create UNAKOR instead (Burim, 2013, p. 189).

Searching for allies, in the early 1920s, I. Poltavets-Ostrianytsia established contacts with the leaders of the National Socialist Movement in Germany, A. Hitler and A. Rosenberg. Several letters of I. Poltavets-Ostrianytsia to A. Hitler (20 April 1923, 27 May 1935) showing these contacts have been preserved. In them, the UNAKOR leader expressed readiness 
to cooperate with Germany, subject to the obligations of the Brest-Lithuania Peace Treaty. In the 1920s - 1940s, contacts were made with the German side with varying intensity and effectiveness. Since the outbreak of the German-Soviet War, UNAKOR has supported the occupiers (Bondarenko, 2016b, p. 26).

Serious image damage of UNAKOR was caused by an open trial against a group of its members accused of anti-Polish subversion and espionage in favor of Germany. In September 1936, Polish police arrested leading figures of the movement. On 27-30 April 1937, a trial of 44 UNAKOR members and their leader I. Voloshyn took place in Lutsk. Only two defendants were acquitted, the rest were imprisoned for a long time. On 15 July 1939, 13 members of the UNAKOR centers in Zapillia village of the Liuboml district of Volyn region were arrested, eight of whom were imprisoned (Tronko, 2010, p. 17).

The Analysis of Recent Research and Publications. The problem of studying Ukrainian emigration in general and the activities of the Ukrainian National Cossack Movement have been the subject of research by a number of Ukrainian researchers. In particular, a thorough research on the impact of interwar Ukrainian political emigration on the social life of the Volyn Voivodeship was prepared by Ruslana Davydiuk (Davydiuk, 2016; Davydiuk, 2018). The development of scientific and educational activity of Ukrainian emigration was investigated by A. Portnov (Portnov, 2008). In the context of the study of Ukrainian-Jewish relations in Western Ukrainian lands, UNAKOR was analyzed by M. Hon (Hon, 2005). The works of V. Kosyk, H. Prokoptschuk, Yu. Kaliberda, O. Savchuk, and T. Ostashko are devoted to the studies of the life and battle path of Ivan Poltavets-Ostrianytsia (Kosyk, 1993; Prokoptschuk, 1958; Kaliberda, 2011; Savchuk, 1993; Ostashko). Ivan Poltavets-Ostryanytsia's little-known letters to Adolf Hitler were published by D. Burim (Burim, 2013). The works of V. Bondarenko, V. Lobodaiev, T. Ostashko, and V. Troshchynskyi are devoted to the issues of formation, transformation and peculiarities of Cossack movement activity in Ukraine and abroad (Bondarenko, 2016a; Lobodaiev, 2010; Ostashko, 2000; Troshchynskyi, 1994). The documentary array of Ukrainian emigration is analyzed in the work of Tetiana Boriak (Boriak, 2011). The researchers from Ternopil Andrii Kryskov and Volodymyr Hruzin devoted their work particularly on the formation of the Ukrainian National Cossack Movement (Kryskov, Hruzin, (n. d.)). In these works, the statute of the Society was often mentioned, but no attempt was made to analyze it in detail.

The purpose of the research is to publish and analyze the statute of the Ukrainian National Cossack Movement (UNAKOR) (1935) as a source for the history of the specified organization and legal culture of the Ukrainian Cossack movement.

The Statement of the Basic Material. Continuing to combat any dissent, possible manifestations of anti-Soviet activity (both in the past and in the 1950s), law enforcement agencies began to develop former members of the Ukrainian National Cossack Movement, which, after the end of the German-Soviet War, was returned to their previous place of residence largely repatriated, tried to establish ties with their fellow-citizens and relatives who lived in Volhyn (SSA SSU, f. 2, d. 8 (1959), c. 3, pp. 122-123). In order to intensify the development of UNAKOR members, to identify their practical anti-Soviet activities, and to intercept communication channels abroad, Soviet law enforcement bodies used an agency (recruited five agents from former UNAKOR members), while seeking through this agency opportunities to acquire a new agency (SSA SSU, f. 2, d. 8 (1959), c. 3, p. 124).

At the same time, on 21 July 1952, by a corresponding decree, Deputy Chief of Division 2 of Section 4 of the Office 2-N of the Ministry of Security of the Ukrainian SSR, Senior 
Lieutenant Babych, extracted materials in separate proceedings from the case No. 96 that described the activities of Ukrainian Cossack organizations during the Nazi occupation. In particular, the above materials contained the statute (1 June 1935) of the Ukrainian National Cossack Movement, an instruction for the military administration of Ukrainian Cossacks, and a translation from German of "Ideology of Ukrainian Free Cossacks" (SSA SSU, f. 2, d. 8 (1959), c. 3, pp. 1-2). In addition to the organizational documents in the newly formed case, records of UNACOR's activity and records of interrogations of its members are kept.

Soviet security officials had accurate information about the origins of the movement, the ideological basis and the governing body. In particular, in a memorandum prepared on the basis of the analysis of investigative and agent materials, security officers claimed that the UNAKOR corps began to form in the territory of the Volyn region in 1924; it was organized by Ivan Voloshyn and headquartered in Lutsk. The number reached about 600 participants. Organizational instructions for practical work came directly from Hetman I. Poltavets-Ostrianytsia. In 1936 - 1937 I. Voloshyn together with the headquarters was relocated to Horokhiv, Volyn region. In 1939, during the annexation of Western Ukraine to the USSR, I. Voloshyn and the headquarters moved to Holm (Poland) (SSA SSU, f. 2, d. 8 (1959), c. 3, p. 120). Until 1942, I. Voloshyn was in charge of leading the UNAKOR members through Ivan Sytnyk (who, as of October 1952, lived in Kolomyia and worked in the Office of Coal Exploration). In 1942 I. Voloshyn returned to Horokhiv. Immediately afterwards, he was arrested by the Ouns and shot dead (Pustomyty village of Lokachi district, Volyn region). Therefore, the head of UNAKOR in Horokhiv district remained Porfyrii Sytnyk. In 1943, UNAKOR numbered up to 250 people and extended its activities to the Horokhiv, Berestechkiv and Senkevichi districts (SSA SSU, f. 2, d. 8 (1959), c. 3, p. 121). During the German-Soviet War, the UNAKOR organization operating in Volyn region was armed and carried a security and police service (SSA SSU, f. 2, d. 8 (1959), c. 3, p. 132).

The governing body of the organization was the committee, which consisted of the most active UNAKOR members, headed by the Ataman. The committee consisted of departments: organizational, administrative, propaganda and intendant. The organizational department was in charge of Cossack military training, arms supplies, uniforms, recruiting and admission of new members. The administrative department managed the internal affairs of the organization. In addition, through the head of this department, communication was made with UNAKOR commandant, gendarmeries, the Cossacks were supervised and the issue of their life was resolved. The propaganda department conducted agitation and propaganda among the Cossacks and the population aimed at attracting new people to UNAKOR, held rallies and spread appeals to the population. The intendant department was supplying the organization with food.

The entire rank-and-file structure of UNAKOR was united in one sotnia. The sotnia was divided into divisions. In the short term, it also included the Cavalry Cossack Division, numbering about 20 people. It was made up of Don Cossacks who were evacuated by the Germans with their families at the time of the advance of Soviet troops on the Don (SSA SSU, f. 2, d. 8 (1959), c. 3, p. 39). However, this department existed for about a month and was disbanded because there was no common ground for horse feed. The leader of the sotnia in their activities directly reported to the head of the organizational department. Under the command of the sotnyk there were unit commanders who conducted military training with the Cossacks. Initially, the sotnia had 20 rifles, a submachine gun, grenades and consequently 30 rifles and a machine gun. The team of the organization was armed with revolvers (SSA SSU, f. 2, d. 8 (1959), c. 3, p. 40). 
At the beginning of September 1943, a part of the UNAKOR in the city of Horokhiv was selected for military training and moved to Starokostiantyniv (now - Starokostiantyniv district of Khmelnitskyi region). After completing a three-week training course, the UNAKOR members had to return to Horokhiv. However, on the way back after training, they were captured by Bandera members and taken with them to the forest. Therefore, these UNAKOR members acted as part of the UPA formations (SSA SSU, f. 2, d. 8 (1959), c. 3, pp. 41, 44).

UNAKOR had been in Horokhiv since its foundation - mid-1943 until the end of January - early February 1944, after which it moved to Kamianka in Lviv region. It located there for about three weeks, and then returned to Horokhiv because of the intense activity of the Soviet guerrillas (SSA SSU, f. 2, d. 8 (1959), c. 3, p. 48).

The main document for UNAKOR's activities was the Statute. The Statute of the Ukrainian National Cossack Movement (UNAKOR) in its original version is stored in the Sectoral State Archive of the Security Service of Ukraine (f. 2: Department of Combating Banditry of the Ministry of Internal Affairs, Department 2-N and Department 4 of the MSS-KGB of the Ukrainian SSR, d. 8 (1959), c. 3 (Control-supervising case with materials on management and control over agent-operative work against the so-called Ukrainian National Cossack Movement "UNAKOR"), pp. 23-25). Another copy of the statute of the Ukrainian National Cossack Movement (UNAKOR) is to be found in the Central State Archives of Higher Authorities and Administration of Ukraine in Kyiv (f. 4465: Collection of Documentary Materials of Ukrainian Nationalist Emigrant Institutions, Organizations and Persons, d. 1, c. 296, pp. 1-3). In this article we use a document from the Sectoral State Archive of the Security Service of Ukraine.

A number of researchers believe that the political provisions outlined in the UNAKOR Statute are close to those of the early German National Socialist and Italian fascist movements (Bondarenko, 2016b, p. 22; Hon, 2005, p. 128; Hon, Zaremba, Kozerod, Pohrebynska, Podolskyi, \& Turov, 2011, p. 154). The efforts of I. Poltavets-Ostrianytsia to bring UNAKOR ideology closer to the national-socialist one were due to the desire to gain the support of Germany. However, the Gestapo did not recommend cooperating with this organization because it considered it to be a small, paper-only entity (as of 1935 it had united approximately 300 people in Volhyn) (Kosyk, 1993, p. 55; Hon, 2005, p. 128; Hon, Zaremba, Kozerod, Pohrebynska, Podolskyi, \& Turov, 2011, p. 154).

The Statute of the Ukrainian National Cossack Movement (UNAKOR) was approved on 1 June 1935 by the UNAKOR Military Administration and signed by military clerk I. Voloshyn and military osavul V. Zolotarenko. The Statute is divided into three sections: I - a historical sketch of the movement (10 subparagraphs); II - UNAKOR program (26 subparagraphs); III - UNAKOR Regulamine (19 subparagraphs).

The first one provides a historical overview of the development of the Cossack movement. It is emphasized that the traditions of the Cossack movement were revived on 3 October 1917, outlining the goals for which the activities were directed. Therefore, the main stages of the formation of the restored Cossack movement and its participation in the processes of state formation are outlined. By the way, this section clearly distinguishes the hetman P. Skoropadskyi's identity into the background and putting I. Poltavets-Ostrianytsia in the foreground.

The second section reveals the programmatic goals of UNAKOR. The primary focus is on the right of self-determination on the basis of which the Organization seeks to restore the independence of the Ukrainian Hetman-Cossack state. It is emphasized that hetmanate is the 
only natural form of organization of state power in Ukraine. Authorities should be formed on the basis of extra-class and non-partisan principles.

The foundations of a monarchical form of government were laid - at the head of the state was a life-long elected Hetman, whose power extended to all territories and was based on the whole people, without class or party preferences. Hetman was the guarantor of national and social equality of all citizens. At the same time, it was emphasized that the reconstruction of the state had to be carried out taking into account the traditions and history of the Cossack era.

The Statute called on the international community to hold a referendum on the issue of determining independence under the control of the international commission and the protection of the international police. In foreign relations, the basic vector was outlined - cooperation with all states and peoples who support independence and statehood. All visitors were guaranteed full protection in accordance with state laws. However, they were strictly forbidden to interfere in the internal affairs of the state.

It was clearly stated that the right to work in government and the legislature belonged exclusively to citizens. The principle of appointment to public office was established not by party affiliation, but by professional criteria, personal qualities and achievements.

The general equality of all citizens was determined. The collective should prevail over the individual - the interests of the state should prevail over the interests of the individual citizen.

The socio-economic foundations of the future state were outlined. State control over large private enterprises remained. The need to resolve the land issue for landless and smallholder citizens was declared. Free lands and large estates of any form were to be transferred to the State Land Fund, from which both the respective national-state enterprises and individual citizens were to be granted in the form and norm established by state law.

There was a need for a complete revision of the legal framework, the development of new laws that should have been based on Cossack traditions.

State guarantees were given to orphans, widows, persons with disabilities, in case of disability, etc. The need for a general secondary education was emphasized and the ability of capable and talented to receive a higher education was highlighted. Much emphasis was placed on physical health and the promotion of sports. Freedom of religion was determined. At the state level, the Ukrainian Autocephalous Orthodox Church was recognized.

The third section described the principles of UNAKOR's internal structure, regulating its use as a governing body for the fight for the state reconstruction of Ukraine. The parliamentary model of government was rejected as ineffective under the circumstances. It was emphasized that it was not the programs, but the frames that bring them to life, that are crucial. It was necessary to prepare the masses for the struggle and education of the youth, which would give adequate resistance to all the invaders.

UNAKOR was located on the territory of Ukraine; it had a vertical construction to which the personnel were personally selected. However, the headquarters were located abroad, with offices of UNAKOR in a number of countries. The functional structural bodies of UNAKOR were the villages (at least 15 people) and farms (at least 5 people).

To join the ranks of UNAKOR, it was necessary to apply to the stanitsa resident or village ataman and to recognize the statute.

Exception from the ranks of UNAKOR was exercised by the ruling starshyna, but the act was authorized by the UNAKOR management center. An emphasis was placed on the observance of decent military behavior, which was supposed to inspire both him and the movement as a whole. 
The statute eliminated UNAKOTO and the UNC, instead created a new organization, UNAKOR, as a direct successor to the Free Cossacks, founded at the Chygyryn congress on 3 October 1917.

The Conclusions. Thus, the Statute of the Ukrainian National Cossack Movement (UNAKOR) was approved on 1 June 1935 by the UNAKOR Military Authority and signed by military clerk I. Voloshyn and military osavul V. Zolotarenko. Although this document is known to researchers, it has not been analyzed separately as a historical source. The statute in its original version is kept in the Sectoral State Archive of the Security Service of Ukraine and the Central State Archives of Higher Authorities and Administration of Ukraine in Kyiv. In this article we use a document from the Sectoral State Archives of the Security Service of Ukraine. The Statute is divided into three sections: I - a historical sketch of the movement (10 subparagraphs); II - UNAKOR program (26 subparagraphs); III - UNAKOR Regulamine (19 subparagraphs). We consider it an important historical source for the history of the functioning of the whole Cossack movement and the history of the development of domestic legal thought.

The document is published in the original language. The edition retains the vocabulary, authoring and editorial features of the source as much as possible. Own and geographical names are presented without changes. Only the most obvious grammatical errors were corrected. The document is accompanied by a legend, indicating the place of its storage (the name of the archive, the number of the fonds, descriptions, cases, pages).

Acknowledgments. The authors of the publication express the sincere gratitude to the director and the employees of the Sectoral State Archive of Security Service of Ukraine for the support and assistance in search of the archival material.

Funding. The authors received no financial support for the research, authorship, and/or publication of this article.

\section{СТАТУТ Українського Національного Козацького Руху “УНАКОР”. \\ The document}

I.

Історичний нарис руху.

Волею Всеукраїнського Козацького 3’їзду від 3-го жовтня 1917 року в м. Чигирині на Київщині було відроджене Українське Козацтво.

Вважаючи себе авангардом в боротьбі за Самостійну Українську ГетьманськоКозацьку Державу, Українське Козацтво стало до праці на захист нижче наведеного програму:

1. Самостійна Українська Гетьмансько-Козацька Держава.

2. Союз Українських Земель.

3. Тверда національна державна влада.

4. Організація козацького війська, як головної підвалени самостійности і державности України.

5. Вирішення земельного питання на користь малоземельного і безземельного громадянства.

6. Забезпечення законом українським робітникам їх соціальних прав і інтересів.

7. Негайне проголошення автокефалії української православної Церкви.

8. Союз з Козацькими та Кавказькими Державами. 
9. Мир і порозуміння з державами почвірного союзу.

10. Українське козацтво, оббіраючи Військову Старшину і Раду, надає їм право кооптації та право вироблення і зміни Статуту.

Українська козацька рада працювала по організації козацтва під проводом першого козацького ідеолога і діяча Військового Отамана Івана Полтавця Остряниці до січня 1918 року в м. Білій Церкві на Київщені, а потім, з посуненям німецького війська на Україну, в м. Києві.

Усунувши в квітні 1918 року інтернаціонально-соціалістичний Уряд Центральної Ради та встановивши на Україні ГЕТЬМАНАТ, - Козацтво продовжувало далі свою працю по організації національно-державних сил українського козацького народу і навіть добилося через Івана Полтавця Остряницю /обраного тоді вже Генеральним писарем України/, від Гетьмана України Універсалу 16 жовтня 1918 року, що накреслював початковий грунт до традицийного козацького державного устрію на Україні. Хоч і вузько були означені права козацького народу в сьому гетьманськім універсалі, всеж дав він змогу довести козацькі лави до 15000 козацьких родин.

14 грудня 1918 р. Павло Скоропадський, зрікся своїх гетьманських прав наступною Грамотою:

“Я, Гетьман усієї України, на протязі семи з половиною місяців прикладав усіх своїх сил, щоб вивести край з того тяжкого становища в якім він перебуває. Бог не дав мені сили справитись 3 цим завданням, і нині я, з огляду на умови, які тепер склались, керуючись виключно добром України, ВІДМОВЛЯЮСЬ ВІД ВЛАДИ. 14.ХІІ.18. Київ.”

Павло Скоропадський

/див. Д. Дорошенко. “Історія України” т. II. стор. 424./

По зреченню Гетьмана, та 3 приходом до влади Діректорії УНР Козацтво стало творити полки і загони для боротьби з ворогами України під проводом таких славних борців як Балбачан, а почасти вимушено було вийти на скитальщену як і за часів Мазепи та Орлика.

4-го вересня 1920 року в Берліні, частина Військової Козацької Старшини, за виключенням б. Гетьмана Скоропадського, що по проголошенню федерації з Москвою, грамотою від 14.XII.18 зрікся від гетьманських прав, - одноголосно постановила відновити працю по організації козацтва під проводом Військового Отамана і Генерального писара України полковника Івана Полтавця Остряниці.

В березні 1921 року осідком штабу Військового Отамана став Мюнхен, де в той час виходив до життя молодий націонал-соціалістичний німецький рух. Близість сього руху, а також і фашистського національному і соціальному змісті з українським національним козацьким рухом, дало можливість до контакту і співпраці. В 1923-24 виходив український козацький орган “УКРАЇНСЬКИЙ КОЗАК”.

Чим далі, тим сильніше розгорталась увага і прихильність українського козацького народу та його руху з боку впливових національних чинників чужоземних держав, що глибоко розуміли вагу відбудови САМОСТІЙНОЇ УКРАЇНСЬКОЇ ГЕТЬМАНСЬКОКОЗАЦЬКОЇ ДЕРЖАВИ на сході Европи.

Так ішла протягом довгих років, для нашої еміграції може незамітна, але на ділі важлива праця на користь українського козацького народу під проводом полковника Івана Полтавця Остряниці.

I надалі під тим же проводом буде іти Українське козацтво дружними лавами до вибореня САМОСТІЙНОСТИ І ДЕРЖАВНОСТИ українського козацького народу 
на посадах означених Всеукраїнським козацьким зьїздом від 3.Х.17 р. та на основах нижченаведеного Програму Регуляміну під гаслом: - БОГ І УКРАЇНА.

Кожен козак-побратим мусить знати що вороги нашої державности уживають всих засобів аби побивати нас - через нас же самих.

Тому УВАГА! - Будьмо дійсними козаками і не губімо пильности, щоби не стати використаними ворогом: “Козак $є$ від Бога поставлений усім вище і лише свому козакові побратимові $є$ він вірний товариш та свому батькові Військовому Отаманові є він ВІРНИЙ КОЗАК”.

II.

Програма УНАКОР

1. Ми жадаємо САМОСТІЙНОї Української Гетьмансько-Козацької Держави, на основах прав народів на самоозначеня.

2. Державна влада на Україні мусить бути надкласовою і надпартійною, маючи перед собою лише національні і соціальні інтереси українського козацького народу.

3. Сьому завданю відповіда лише наша традицийна історична Гетьманська влада, що обьєднується в особі доживотньо обраного народом: - ГЕТЬМАНА усієї УКРАЇНИ обох боків ДНІПРА та ВІЙСЬК КОЗАЦЬКИХ І ЗАПОРІЖСЬКИХ.

4. Взглядно 3 сим, новітній український Гетьманат має нести 3 собою всенародній спокій і замиреня клясів, тоб то бути Гетьманатом НАДКЛЯСОВИМ і НАДПАРТІЙНИМ. - Він мусить спертись на активні сили нації, тоб то бути Гетьманатом НАЦІОНАЛЬНИМ. - Він мусить упорядкувати соціальне житя народу і забезпечити свобідне виявленя праці продуктивних сил в державних межах тоб то бути Гетьманатом СОЦАЛЬНИМ.

5. Українська народня козацька держава є примушена спертись на свою довговікову і славетню історію козацької доби, бо наше народження тепер, є не шо иньше як висновок незміримих офір боротьби і праці попередніх поколінь. Тому національнодержавне відродження в сучасний мент $є$ поверненям на історичний державний шлях, - але для руху наперед новими та кращими засобами.

6. Ми виступаємо перед цілим культурним світом 3 домаганням допомогти нашій праці і вжити всіх заходів до того аби на радянській Україні, за посередництвом міжнародної комісії та під охороною міжнародної поліції, було як найскоріше переведено всенародне голосованя за САМОСТІЙІСТЬ.

7. Ми ідемо до порозуміння і союзу з сусідніми народами, як також з тими світовими народами які визнають нашу САМОСТІЙНІСТЬ і ДЕРЖАВНІСТЬ.

8. Ми вважаємо членом українського козацького народу того, хто посідає громадянські права української козацької держави, виконує іiі закони та підлягає iii державній владі

9. Чужинці, що перебувають часово на Україні, вважаються яко гості і користуються повним захистом з боку державних законів і установ. Втручання чужинців у внутрішні справи України є заборонено.

Прим: Означене в п. 9, відноситься також і до емігрантів, що преходово чи постійно перебувають на Україні.

10. Право участи в уряді та виробленю державних законів, належить лише громадянам. 
11. Усі державні посади мають обсаджуватись не по партійній приналежности, а лише на основі особистих заслуг перед Державою і Нацією чи на основі особистих здібностей.

12. Ми вимагаємо аби чужинці, що вивандрували на Україну з північного терену сучасного радянського союзу СССР, після 1 березня 1917 року і осіли на постійне життя, - залишили межі України.

13. Усі громадяне української козацької держави мають рівні права і обовьязки. Держава має пеклуватись на сам перед про добробут своїх громадян.

14. Першим обовьязком кожного громадянина $є$ продукувати духовно і фізично на користь Нації і Держави. Діяльність окремих одиниць не може бути скерована проти інтересів загалу, а лише в межах спільних інтересів на загальну користь.

15. Ми жадаємо державного контролю усіх великих приватніх підприємств та участи робітників в прибутку сих підприємств.

16. Ми жадаємо організації установ і домів про пеклування за сиріт, вдов, старість, інвалідів, калік та т. и.

17. Ми жадаємо досконального і кінечного вирішення земельного питання на користь безземельного і малоземельного громадянства на основах прав власности.

18. Вільні землі та великі маєтности усякого вигляду переходять до державного земельного фонду, з котрого мають наділятись як відповідні національно-державні підприємства, так і окремі громадяни в формі і нормі установленій державним законом.

19. Ми жадаємо боротьби закону проти тих хто шкодитиме загальним державним інтересам українського козацького народу.

20. Ми жадаємо повного перегляду законів та вироблення нових які би базувались на традиціях українського козацького народу на укладі його громадського та соціального житя.

21. Ми жадаємо виробленя сістеми загальної шкільної освіти та їх фахів, аби кожен здатний і працьовитий громадянин зміг дійти до вищої освіти і провідництва.

22. Ми жадаємо аби держава пильно дбала про фізичне оздоровлення народу, тому вправи і спорт мають бути обовьязково поширені в народі.

23. Ми жадаємо установлення постійного рекрутово-рейстрового козацького війська, організованого згідно вимогам сучасної стратегії, тактики і техніки.

24. Ми жадаємо свободу усих віросповідань, але також заборони порушення національного, етичного і морального почуття українського козацького народу.

25. Українська автокефальна православна Церква $є$ головною Церквою і має знаходитись під безпосереднім пастирством ПАТРІЯРХІВ всея УКРАЇНИ.

26. Без грошей і маєтків, а лише $з$ вірою в серці в загальне, святе національне діло, підіймаємо ми прапор боротьби за Самостійну українську гетьмансько-козацьку державу та кличемо до праці увесь український нарід на терені і по за ним сущий.

III.

Регулямін УНАКОР

1. - Сила УНАКОР залежить від плянової праці, та від активности і дісціпліни окремих козацьких відділів на Україні і по за ії межами.

2. - УНАКОР веде боротьбу за державну відбудову України згідно вище наведеного статуту. Тому козацтво мусить знати, що парляментаризм не на часі: - Потрібна: ідейність, єдність, активність і дисціпліна. 
3. Український козацький нарід мусить твердо памятати, що йому до сього часу бракувало не програмів, - а людей волі щоби сі програми перевести в житя.

4. Усі питаня українського державного життя та змагань до самостійности, були вже давно розвязані на папері, - бракувало лише людей розуму і волі, аби перевезти їх в дійсність.

5. Тому український козацький нарід в програму УНАКОР мусить зробити собі догмат віри і зачати дихати тією гарячою національною активною силою, без якої $\epsilon$ мертві усякі програми.

6. Коли ми не озброємось сією вірою, не знищемо посеред себе пасивности, не зробимо з нас і молодого покоління граніту об який розібьється кожен чужий молот і меч, - то нас розтлять і поглинуть вороги і нам знову придеця викреслити з нашої історії одну а то і дві сотні років.

7. Тому праця УНАКОР іде на засадах будови організації зверху вниз, шляхом перзонального підбору козаків-побратимів, оминаючи усяке виборче начало.

8. УНАКОР знаходиться на терені України. По за межі України знаходиця лише ідейний керуючий центр та представництва УНАКОР.

9. Права і обовьязки сього ідейного керуючого Центру установлені додатковим Регуляміном внутрішнього керуваня УНАКОР.

10. В метах поширеня руху УНАКОР, закладаються станиці і хутори, як по наказу, так і по властному почину. Станиця: не меньче 15 козаків в одному місті і хутір: не меньче 5 козаків в одному місті.

11. Праця таких станиць, хуторів чи иньших установ УНАКОР, опреділюється окремим наказом центру.

12. Побратимами УНАКОР можуть бути українські козаки і козачки та козаки і козачки самостійники иньших козацьких народів, що визнають Статут і Регулямін УНАКОР.

13. Виключеня з лав УНАКОР, може перевести кожен урядуючий Старшина, але акт про виключеня потребує санкції керуючого центру УНАКОР.

14. Вступивши в лави УНАКОР, кожен побратим має поводитись в усьому яко лицарь, аби сим осягнути поваги серед своїх і чужих як до себе так і до УНАКОР та козацтва.

15. Кожен побратим має твердо пам'ятати про те, що усю свою працю і волю він мусить скерувати до як найширшого зрісту УНАКОР за рахунок ідейних, активних, чесних і дісціплінованих побратимів.

16. Бажаючі вступити в лави УНАКОР, подають Станичному чи Хуторсьному Отаманові заяву слідуючого змісту: “Я/імя прізвище/ вступаючи в лави УНАКОР, заявляю, що свідомо приймаю Статут і Регулямін УНАКОР та словом козацької чести зобовьязуюсь бути активним і дісціплінованим побратимом."

/імя, прізвище. Адреса. Поручителі./

17. День св. Покрови Запорожської Богоматері 1-го жовтня, є днем загального свята українського козацького народу і УНАКОР.

18. Істнувавше Укр. Нац. Коз. Т-во / УНАКОТО/ і Укр. Нац. Коз. /УНК/

$\epsilon$ Керуючим центром УНАКОР - розв'язані і їхні печатки уневажені. Вразі під цією назвою десь зьявляться такі гуртки, то побратими мусять знати що там криються або провокатори, або вороги єдности українського козацтва і про то мусять попередити як центр УНАКОР так і иньші українські нац.орг. та уряд. установи відп. Держави.

19. По справам УНАКОР, належить звертатись на адресу Військової Управи УНАКОР: 
Вище наведений статут і регулямін УНАКОР по дорученю Ідейного Керючого Центру Українського Козацтва

\author{
С Т В Е Р Д И Л А:
}

Військова Управа УНАКОР.

Військовий Писар УНАКОР. Військовий Осавул УНАКОР.

Іван ВОЛОШИН В. Золотаренко

1.6.35. p.

Скитальщина.

The historical source: Sectoral State Archive of Security Service of Ukraine, f. 2, op. 8 (1959), c. 3, pp. 23-25.

\title{
BIBLOGRAPHY
}

Bondarenko, V. H. (2016a). Ukrainskyi vilnokozatskyi rukh v Ukraini ta na emihratsii (1919-1993 rr.) [Ukrainian Free Cossack Movement in Ukraine and Emigration (1919 - 1993)]. Zaporizhzhia: Zaporizkyi natsionalnyi universytet, 600 p. [in Ukrainian]

Bondarenko, V. H. (2016b). Ukrainskyi vilnokozatskyi rukh v Ukraini ta na emihratsii (19191993 rr.) [Ukrainian Free Cossack Movement in Ukraine and Emigration (1919 - 1993)] (Extended abstract of Doctors thesis). Lviv. [in Ukrainian]

Boriak, T. H. (2011). Dokumentalna spadshchyna ukrainskoi emihratsii v Yevropi: Prazkyi arkhiv (1945 - 2010) [Documentary Legacy of Ukrainian Emigration in Europe: Prague Archive (1945 2010)]. Nizhyn: Vyd-vo NDU imeni Mykoly Hoholia, 544 p. [in Ukrainian]

Burim, D. V. (2013). Do istorii ukrainskoho kozatskoho rukhu v emihratsii: lysty Ivana PoltavtsiaOstrianytsi do Adolfa Hitlera [On the History of the Ukrainian Cossack Movement in Emigration: Letters from Ivan Poltavets-Ostrianytsia to Adolf Hitler]. Istorychnyi arkhiv. Naukovi studii, 10, 188206. [in Ukrainian]

Davydiuk, R. (2016). Ukrainska politychna emihratsiia v Polshchi: sklad, struktura, hromadskopolitychni praktyky na terytorii Volynskoho voievodstva [Ukrainian Political Emigration in Poland: Composition, Structure, Socio-Political Practices in Volyn Voivodeship]. Lviv; Rivne, 704 p. [in Ukrainian]

Davydiuk, R. (2018). Ukrainska politychna emihratsiia yak faktor suspilnykh zmin na terytorii Zakhidnoi Volyni [Ukrainian Political Emigration as a Factor of Social Change in the Territory of Western Volhyn]. Naukovi zapysky Natsionalnoho universytetu "Ostrozka akademiia". Seriia "Istorychni nauky", 27, 68-74. [in Ukrainian]

Haluzevyi derzhavnyi arkhiv Sluzhby bezpeky Ukrainy [Sectoral State Archive of Security Service of Ukraine - SSA SSU]

Hon, M. M. (2005). Iz kryvdoiu na samoti. Ukrainsko-yevreiski vzaiemyny na zakhidnoukrainskykh zemliakh u skladi Polshchi (1935 - 1939) [With Resentment Alone. Ukrainian-Jewish Relations in Western Ukraine in Poland (1935 - 1939)]. Rivne: Volynski oberehy, 192 p. [in Ukrainian]

Hon, M. M., Zaremba O. V., Kozerod O. V., Pohrebynska I. M., Podolskyi A. Yu., \& Turov I. V. (2011). Yevreiska hromadsko-politychna dumka XX - pochatku XXI storichchia v Ukraini [Jewish Socio-Political Thought of the Twentieth - Early Twenty-first Centuries in Ukraine]. Kyiv: IPiEND im. I. F. Kurasa NAN Ukrainy, 363 p. [in Ukrainian]

Kaliberda, Yu. (2011). Ivan Poltavets-Ostrianytsia - nakaznyi otaman ukrainskoho vilnoho kozatstva [Ivan Poltavets-Ostrianytsia is an Appointed Ataman of Ukrainian Free Cossacks]. Voienna istoriia, 4 (58), 98-105. [in Ukrainian] 
Kosyk, V. (1993). Ukraina i Nimechchyna u Druhii svitovii viini [Ukraine and Germany in World War II]. Paryzh-Niu-York-Lviv, 684 p. [in Ukrainian]

Kryskov, A., Hruzin, V. (n. d.). Ukrainskyi natsionalnyi kozatskyi rukh (UNAKOR) [Ukrainian National Cossack Movement (UNAKOR)]. URL: http://elartu.tntu.edu.ua/handle/lib/22428 [in Ukrainian]

Lobodaiev, V. M. (2010). Revoliutsiina stykhiia. Vilnokozatskyi rukh v Ukraini $1917-1918 \mathrm{rr}$. [Revolutionary Element. Free Cossack Movement in Ukraine of 1917 - 1918]. Kyiv: Tempora, 672 p. [in Ukrainian]

Ostashko, T. (2000). Ukrainskyi kozatskyi rukh v emihratsii (1919 - 1939) [Ukrainian Cossack Movement in Emigration (1919 - 1939)]. Visnyk Kyivskoho derzhavnoho linhvistychnoho universytetu. Seriia "Istoriia, ekonomika, filosofiia", 4, 285-294. [in Ukrainian]

Ostashko, T. S. (n. d.). Poltavets-Ostrianytsia Ivan Vasylovych [Poltavets-Ostrianytsia Ivan Vasyliovych]. URL: www.history.org.ua/cgi-bin/eiu/history.exe. [in Ukrainian].

Portnov, A. (2008). Nauka u vyhnanni: naukova i osvitnia diialnist ukrainskoi emihratsii u mizhvoiennii Polshchi (1919-1930) [Science in Exile: Scientific and Educational Activity of Ukrainian Emigration in Interwar Poland (1919 - 1930)]. Kharkiv, 256 p. [in Ukrainian] German]

Prokoptschuk, G. (1958). Ukrainer in München [Ukrainer in München]. München, 96 p. [in

Savchuk, O. (1993). Hetmanskyi rukh u Polshchi u 1920 - 30-i rr. [The Hetman Movement in Poland in 1920 - the 30s.]. In Ostannii hetman: Yuvileinyi zbirnyk pamiati Pavla Skoropadskoho 1873 - 1945 [The Last Hetman: Anniversary Collection of Memory of Pavlo Skoropadskyi of 1873 1945] (pp. 167-175). Kyiv: Akadempres. [in Ukrainian]

Tronko, P. T. (Ed.). (2010). Reabilitovani istoriieiu: Volynska oblast (u 27 t., T. 1) [Rehabilitated by History: Volyn Region (in 27 volumes, Vol. 1)]. Lutsk: VAT "Volynska oblasna drukarnia", 976 p. [in Ukrainian]

Troshchynskyi, V. P. (1994). Mizhvoienna ukrainska emihratsiia v Yevropi yak istorychne i sotsialno-politychne yavyshche [Interwar Ukrainian Emigration in Europe as a Historical and Socio-Political Phenomenon]. Kyiv: Intel, 260 p. [in Ukrainian]

The article was received on June 20, 2019.

Article recommended for publishing 26/02/2020. 